\title{
Root Canal Microorganisms Profiles of Upper Anterior Teeth with Periapical Lesion
}

\author{
Maria Tanumihardja ${ }^{1,2}$, Irene E. Riewpassa ${ }^{3}$, Mansjur Nasir ${ }^{4}$, Burhanuddin D.Pasiga $^{5}$ \\ ${ }^{1}$ Department of Conservative Dentistry and Endodontology, Faculty of Dentistry, Hasanuddin University, Makassar \\ 55281 Indonesia \\ ${ }^{2}$ Postgraduate Programme, Faculty of Medicine, Hasanuddin University, Makassar 55281, Indonesia \\ ${ }^{3}$ Department of Oral Biology, Faculty of Dentistry, Hasanuddin University, Makassar 55281, Indonesia \\ ${ }^{4}$ Department of Orthodontics, Faculty of Dentistry, Hasanuddin University, Makassar 55281, Indonesia \\ ${ }^{5}$ Department of Dental Public Health, Faculty of Dentistry, Hasanuddin University, Makassar 55281, Indonesia \\ Corresponding e-mail to: maria_tanumiharja@yahoo.com
}

\begin{abstract}
Microorganisms are the main causative agents on the development of apical periodontitis. Microorganisms infecting the root canal system are colonized in communities as biofilm. These bacterial communities show distinct pattern related to the different forms of apical periodontitis which are determined by species richness and abundance. Objective: This study is aimed to examine the root canal microorganisms on upper anterior teeth of asymptomatic apical periodontitis and chronic apical abscess. Methods: Samples were collected from patients referred to Endodontic Department of Hasanuddin University Dental Hospital from July 2013 to September 2013. Twenty two samples, aged 17-40 were collected from 16 patients with asymptomatic apical periodontitis, and 36 samples, aged 18-50 were collected from 36 patients with chronic apical abscess. Microorganisms were evaluated using cultural technique. Results: The results showed predominant bacteria in asymptomatic apical periodontitis is Porphyromonas spp while in chronic apical abscess both Streptococcus spp and Porphyromonasspp showed similar frequencies. This study showed Porphyromonas spp plays dominant role in apical periodontitis either in asymptomatic apical periodontitis or chronic apical abscess. Conclusion:This study showed different composition of bacteria within different apical periodontitis and Porphyromonas spp is the most prevalent bacteria found in both asymptomatic apical periodontitis and chronic apical abscess.
\end{abstract}

\begin{abstract}
Profil mikroorganisme dalam saluran akar dengan kelainan periapikal. Berbagai mikroorganisme merupakan agen penyebab terjadinya periodontitis apikalis. Mikroorganisme yang menginfeksi sistem saluran akar berkoloni membentuk suatu komunitas biofilm. Jumlah komunitas bakteri ini menunjukkan pola khusus yang terkait dengan bentuk periodontitis apikalis yang terjadi. Tujuan: Melakukan pemeriksaan mikroorganisme di saluran akar gigi anterior atas dengan periodontitis apikalis dan abses apikalis kronis. Metode: Sampel didapat dari pasien yang dirawat di Departemen Endodontik Rumah Sakit Gigi Mulut Universitas Hassanuddin selama Juli-September 2013. Sampel periodontitis apikalis asimtomatis dikumpulkan dari 16 pasien berusia antara 17-40 tahun dan sampel abses apikal kronis didapat dari 36 pasien berusia 18-50 tahun. Identifikasi jenis mikroorganisme dilakukan dengan metode kultur. Hasil: Penelitian ini menunjukkan bahwa bakteri yang mendominasi periodontitis apikalis asimtomatis adalah Porphyromonas spp, sedangkan dalam abses apikalis kronis, Streptococcus spp dan Porphyromonas spp mempunyai frekuensi yang sama. Oleh karena itu, Porphyromonas spp mempunyai peran dominan dalam periodontitis apikalis dan abses apikalis kronis. Simpulan: Penelitian ini menunjukkan perbedaan komposisi bakteri yang ada dalam periodontitis apikalis dan abses apikal kronis, namun Porphyromonas spp merupakan bakteri yang mendominasi keduanya.
\end{abstract}

Key words: apical periodontitis, culture technique, microorganism, root canal 


\section{INTRODUCTION}

Apical periodontitis, an inflammatory process around the apical area of teeth is primarily caused by microorganisms infecting the root canal system. Many studies demonstrate the presence of different features of the microorganisms associated with different types of endodontic infection and different forms of apical periodontitis. ${ }^{1,2}$ In addition, there is great variability in endodontic communities of each person in terms of specific richness and abundance. Different geographic locations also determine these differences. The consistency of different composition of endodontic microorganisms among individuals shows the heterogeneous etiology of apical periodontitis where combination of multiple species may lead to similar disease outcomes. ${ }^{1,3-}$ ${ }^{6}$ Asymptomatic apical periodontitis shows a dynamic process between host defense in apical area and infected bacteria in the root canal system, which can develop to chronic apical abscess when bacteria evade from massive host PMN attack. ${ }^{7}$ The rationale of root canal therapy is to provide an aseptic condition of root canal system by eliminating the microorganisms and preventing them from infecting the root canal and/or the periapical tissues. A thorough understanding of the endodontic microbiota involved in different type of apical periodontitis is essential for the success of endodontic treatment. ${ }^{8}$ The present study was aimed to provide additional information to the knowledge of microorganisms infecting the root canal system with apical periodontitis.

\section{METHODS}

\section{Case selection}

This study was conducted on 58 single-rooted teeth of patients referred to the Endodontic Department, Dental Hospital of Hasanuddin University, between July to September 2013. Medical and dental histories were taken as routine procedures at the clinic. All cases were asymptomatic at the time of sample collection, and 36 samples had sinus tracts. Patients with a systemic disease, periodontal pockets deeper than $4 \mathrm{~mm}$ or those who had taken antibiotics in the last three months were excluded from the study. An informed consent was taken from each patient prior to the study.

\section{Sampling}

Sampling was carried out under aseptic conditions. The tooth was isolated with cotton roll, desinfected using 3\% hydrogen peroxide and $2.5 \%$ sodium hypochlorite for 30 second before accessing the canal. The softened dentine was removedby excavating until the pulp was exposed. Canal access was checked by inserting a \#20 K-file. A little amount of sterile saline was irrigated into the root canal to moisten it. Sampling was performed by placing a sterile paper point \#25 into the canal for 60secs. Following removal from the canal, the paper point was immediately put into a screw-cap container filled with $3 \mathrm{~mL}$ transport medium of Cary Blair agar. The container was directly sent to the microbiology laboratory.

\section{Isolating and detection of species}

The paper point was taken out from the container and inserted into the other container filled with enhancement medium of Brain-Heart Infusion Broth (BHIB), incubated anaerobically for $24 \mathrm{~h}$ at $37^{\circ} \mathrm{C}$ in gas vac. One $\mathrm{mL}$ of cultivated bacteria, added with $9 \mathrm{~mL} \mathrm{NaCl} 0.9 \%$ were diluted and repeated in 3 series until it reached $10^{3} \mathrm{CFU}$ bacteria. In the third container with $10^{3} \mathrm{CFU}$ of bacteria, $1 \mathrm{~mL}$ was taken and swabbed on a sterile petri dish. Nutrient Agar (NA) was poured into the dish and then incubated, anaerobically, using gas vac for $24 \mathrm{~h}$ at $37^{\circ} \mathrm{C}$. The appeared colonies were counted conventionally and then were stained for morphology of bacterial cells. ${ }^{9}$

\section{RESULTS}

Out of 58 samples, 22 were diagnosed with asymptomatic apical periodontitis and 36 were diagnosed with chronic apical abscess. In the cultured plates, 54 plates had only one predominant species and 4 plates had two predominant species. With regard to asymptomatic apical periodontitis, 18 teeth had only one predominant species, while the remaining 4 teeth had two predominant species. In teeth with chronic apical abscess, each sample showed only one predominant species.

Porphyromonas spp was the most prevalent species in teeth with asymptomatic apical periodontitis, followed by Propionibacterium spp and Streptococcus spp. Meanwhile, in teeth with chronic apical abscess, Streptococcus spp was the most prevalent species followed by Porphyromonas spp and Propionibacterium spp. The prevalent bacteria found from the root canals of asymptomatic apical periodontitis and chronic apical abscess are presented in Table 1 and 2, respectively.

The distribution of species type in the teeth with asymptomatic apical periodontitis and chronic apical abscess are presented in Figure 1 and 2, respectively.

\section{DISCUSSION}

Primary root canal infections are the cause of primary apical periodontitis which can become into chronic or acute state of disease. Root canal systems of primary infections are occupied by mixed community of bacteria, but dominated by anaerobic bacteria, ${ }^{1}$ as also found with asymptomatic apical periodontitis in this study (Figure 1). Although infected root canal system becomes 'a privileged sanctuary' for bacterial growth, 
Table 1. The prevalence of bacteria from the root canals of teeth with asymptomatic apical periodontitis

\begin{tabular}{lcc}
\hline Species & Frequency (n) & Prevalence (\%) \\
\hline Porphyromonas spp. & 10 & 31.3 \\
Propionibacterium spp. & 5 & 15.6 \\
Streptococcus spp. & 4 & 12.5 \\
Bacteroides spp. & 3 & 9.4 \\
Eubacterium spp. & 3 & 9.4 \\
Actinomyces spp. & 2 & 6.3 \\
Candida spp & 4 & 12.6 \\
Fusobacterium spp. & 1 & 3.1 \\
\hline
\end{tabular}

Table 2. The prevalence of bacteria from the root canals of teeth with chronic apical abscess

\begin{tabular}{lcc}
\hline Species & Frequency (n) & Prevalence (\%) \\
\hline Streptococcus spp. & 20 & 50.0 \\
Porphyromonas spp. & 15 & 41.7 \\
Propionibacterium spp. & 3 & 8.3 \\
\hline
\end{tabular}

Table 3. Distribution of facultative and obligate anaerob bacteria from the root canals of teeth with asymptomatic apical periodontitis and chronic apical abscess

\begin{tabular}{lcc}
\hline & Facultative Anaerob & Obligate Anaerob \\
\hline \multirow{3}{*}{ Gram +} & Streptococcus spp. & Eubacterium spp. \\
& Propionibacterium & Bacteroides spp. \\
Gram - & spp. & Actinomyces spp. \\
& & Porphyromonas spp. \\
Yeasts & & Fusobacterium spp. \\
\hline
\end{tabular}

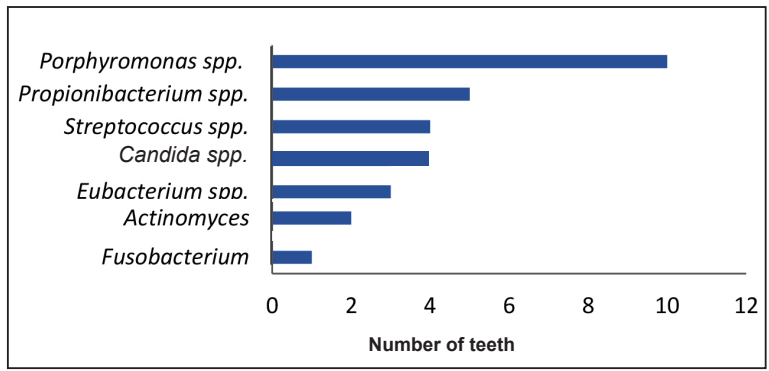

Figure 1. The frequency of bacteria from root canals of teeth with asymptomatic apical periodontitis

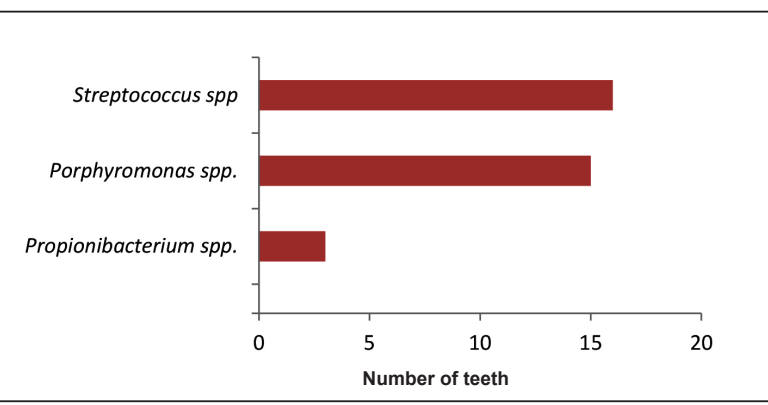

Figure 2. The frequency of bacteria from root canals of teeth with chronic apical abscess only selected species can survive in a root canal. ${ }^{10-12}$ The ecological factors have been reported to determine the survival of the root canal microorganisms, including nutrients availability, oxygen tension, temperature, $\mathrm{pH}$ and interactions between bacteria. ${ }^{10}$ Several studies have shown positive associations in the presence of particular species, such as Fusobacterium spp is associated with Porphyromonas spp micros (Table 3). The tendency to associate these species is related to their similar properties as an anaerobic and ferment amino acids and peptides. ${ }^{12}$ The presence of Streptococcus spp in higher proportion either in asymptomatic apical periodontitis or chronic apical abscess may indicate a direct communication of root canal systems to the oral cavity that provide energy from carbohydrate fermentation for their growth (Table 1-2). ${ }^{12}$ In this study, the proportions of Streptococcus spp. (44.4\%) outnumbered Porphyromonas spp (41.7\%) in chronic apical abscess, which indicates a long-standing infection that favors dominance towards selected species. ${ }^{11}$ Streptococcus spp is also usually observed in persistent periapical lesions of root-filled teeth and has significant positive associations with the presence of a sinus tract. ${ }^{13}$ Love et al reported that binding specificity of streptococcal antigen I/II polypeptide facilitates coinvasion of dentinal tubules by Porphyromonas spp and Streptococcus spp which may increase their virulence. ${ }^{14}$

In this study, bacteria from asymptomatic apical periodontitis are more diverse compare to bacteria from chronic apical abscess (Figure 1), however Porphyromonas spp is the most prevalent microorganism found in root canals either with asymptomatic apical periodontitis or with chronic apical abscess. This result showed similar findings with previous studies as detected in endodontic infections of patients from Oregon, US and Brazil using molecular study. ${ }^{4-6}$ However samples from South Korean patients showed different pattern with Fusobacterium spp as the most prevalent. ${ }^{5}$ A study using a reverse-capture checker board hybridization assay also recorded different bacteria as Olsenellauli was the most prevalent microorganism taxa from samples of infected root canals with chronic periapical periodontitis. ${ }^{3}$ These findings remain to be clarified whether the prevalence of some species in endodontic infections vary according to geographic location or to inter-individual variabilities. This may indicate that multiple bacterial conditions can play a role in apical periodontitis. ${ }^{3}$

This study also found yeast namely Candida spp, was identified in the root canals of 3 samples with asymptomatic apical periodontitis. Although yeasts are rare inhabitants of untreated root canals, their occurrence was reported in $21 \%$ of samples with primary endodontic infections using molecular study. ${ }^{15}$ Their presence is caused by direct communication of exposed pulp to the oral cavity and needs further study to clarify this observation whether it has relevant therapeutic implications. ${ }^{16}$ 
Despite diverse expands in methodologies of bacterial detection in the root canal system, no single method can provide all the information. Microbial culture has been traditionally used to examine the endodontic microbiota. ${ }^{9}$ Although culture method has many limitations, it has some advantages in determining the viable bacteria cells found in the root canal system. It also allows quantification of major viable microorganisms in the samples as observed in this study.

\section{CONCLUSION}

In conclusion, this study showed different composition of bacteria within different apical periodontitis, and Porphyromonas spp is the most prevalent bacteria found in both asymptomatic apical periodontitis and chronic apical abscess.

\section{ACKNOWLEDGEMENTS}

This study was supported by grants from the Institute for Research and Community Services (BOPTN 2013), Faculty of Dentistry, Hassanuddin University. The authors thank Markus Lembong for excellent technical assistance at Department of Microbiology, Medical Faculty, Hassanuddin University.

\section{REFERENCES}

1. Siqueira JF, Roqas I. Distinctive features of the microbiota associated with different forms of apical periodontitis. J Oral Microbiol. 2009;1:1-17.

2. Peciuliene V, Maneliene R, Balcikonyte E, Drukteinis S, Rutkunas V. Microorganisms in root canal infections: a review. Stomatologija Baltic Dent Maxillofac J. 2008;10:4-9.

3. Rocas IN, Siquiera JF Jr. Root canal microbiota of teeth with chronic apical periodontitis. J Clin Microbiol. 2008;4611:3599-606.

4. Siqueira JF, Jung IY, Rocas IN, Lee CY. Differences in prevalence of selected bacterial species in primary endodontic infections from two distinct geographic locations. Oral Surg Oral Med Oral Pathol Oral Radiol Endod. 2005;995:641-7.
5. Rocas IN, Baumgartner JC, Xia T, Siqueira JF. Prevalence of selected bacterial named species and uncultivated phylotypes in endodontic abscesses from two geographic locations. J Endod. 2006;32:1135-8.

6. Baumgartner JC, Siqueira JF Jr, Xia T, Rocas IN. Geographical differences in bacteria detected in endodontic infections using polymerase chain reaction. J Endod. 2004;30:141-4.

7. Metzger Z, Abramovitz I: Periapical lesions of endodontic origin. In: Ingle's Endodontics 6. 6th Ed. Ingle JI, Bakland LK, Baumgartner JC. BC Decker Inc Hamilton. 2008. p.500.

8. Narayanan IL, Vaishanavi C. Endodontic microbiology. J Conserv Dent. 2010:13:233-9.

9. Baumgartner JC, Siqueira JF Jr, Sedgley CM, Kishen A. Microbiology of endodontic disease. In : Ingle's Endodontics 6. 6th Ed. Ingle JI, Bakland LK, Baumgartner JC. BC Decker Inc Hamilton. 2008. p. 228.

10. Siqueira JF, Roqas IN, Alves FRF, Silva MG.. Endodontic infections : Concepts, paradigms and perspectives. Oral Surg, Oral Med Oral Pathol Oral Radiol Endod. 2009;107:721-6.

11. Figdor D, Gulabivala K. Survival against the odds: microbiology of root canals associated with post-treatment disease. Endodontic Topics. 2010;18:62-77.

12. Figdor D, Sundqvist G. A big role for the very small-understanding the endodontic microbial flora. Aus Dent J. 2007;52:S36-S51.

13. Pinheiro ET, Gomes BP, Ferraz CC, Sousa EL, Teixeira FB, et al. Microorganisms from canals of root-filled teeth with periapical lesions. Int Endod J. 2003;36:1-11.

14. Love RM, Mc Millan MD, Park Y, Jenkinson HF. Coinvasion of dentinal tubules by Porphyromonas gingivalis and Streptococcus gordonii depends upon binding specificity of streptococcal antigen I/II adhesion. Infect Immun. 2000;68:1359-65.

15. Baumgartner JC, Watts CM, Xia T. Occurrence of Candida albicans in infections of endodontic origin. J Endod. 2000;26:6958.

16. Gajan EB, Aghazadeh M, Abashov R, Milani AS, Moosavi Z. Microbial flora of root canals of pulpally-infected teeth: Enterococcus faecalis a prevalent species. J Dent Res Dent Clin Dent Prospects. 2009;3:24-7. 